\title{
MITTEILUNGEN DER SCHWEIZER INFORMATIK GESELLSCHAFT / 5_2014 \\ Schweizer Informatik Gesellschaft
}

Société Suisse d'Informatique

Società Svizzera per I'Inform

Swiss Informatics Society

Präsident: Prof. Dr. Bernhard M. Hämmerli

e-mail: admin@s-ich,

http://www.s-i.ch/

Informationen

\section{Das Netzwerktreffen „Technologieoutlook \\ und IT-Trends als Chance \\ für den Geschäftserfolg "s}

Weitere Informationen erhalten Sie

bei http://www.future-network.at/.

\section{ICT Proposers' Day - Florence,}

Italy 9-10 0ctober

Please register http://ec.europa.eu/ digital-agenda/events/cf/ictpdi4/

register.cfm.

It's the main European $\mathrm{H}_{2} \mathrm{O} 2 \mathrm{O}$

ICT summit of the year. Over 3000

participants are expected in Florence

in October 2014.

It covers most of the Societal Challenges, as well as ICT, see the list of topics covered here https://ec.europa.eu/digital-agenda/ events/cf/ictpd14/topics.cfm.

There will be a number of further activities at the ICT Proposers day including a brokerage (face 2 face pre-arranged meetings) to facilitate networking.

\section{World's largest civilian robotics programme launched}

The European Commission (EC) and 180 companies and research organisations launched the world's largest civilian Research and Innovation (R\&I) programme in robotics, http://sparc-robotics.eu/.
SPARC is a contractual PublicPrivate Partnership (PPP) based on an agreement signed on 17 December 2013 between the EC and http://www.eu-robotics.net/, which represents European stakeholders from industry and academia. SPARC runs under the priority "Leadership in Enabling and Industrial Technologies" (LEIT) of Horizon 2020. The PPP should facilitate the growth of the robotics industry from fundamental research to the commercialisation of innovative products and applications and help maintain and extend Europe's leadership in robotics. The initiative is expected to create over 240.000 jobs in Europe, and increase Europe's share of the global market from $32 \%$ to $42 \%$, which represents a boost of $€_{4}$ billion per year.

With $€ 700$ million in funding from the EC for 2014 to 2020, and triple that amount from the industry, SPARC is the largest civilian-funded robotics R\&I programme in the world. First calls will be published in October 2014.

\section{Fachgruppe Knowledge Structures and Metadata (KSM)}

Möchten Sie neue Erfahrungen zu den Themen Taxonomien, freies Vokabular (Folksonomy), unstrukturierte oder strukturierte Daten sammeln und austauschen, dann sind Sie bei der Fachgruppe Knowledge Structures and Metadata (KSM) bestens aufgehoben.

Die Fachgruppe KSM bietet Ihnen Beratung, Austausch und Vermittlung für den Einsatz von computergestützen Wissenstrukturen in der Praxis. Ziel ist es, eine Networkingplatform mit Forschern und Praktikern aufzuziehen, um intelligentere Anwendungen und Prozesse $\mathrm{zu}$ entwickeln und anzubieten.

Gerne laden wir interessierte Personen aus Wirtschaft, Verwaltung und Forschung ein, die sich mit uns in Verbindung zu setzen.

Weitere Informationen: http:// www.s-i.ch/fachgruppen-undsektionen/ksm-knowledge-structuresand-metadata/.

\section{Cloud Computing}

SIG CC: Tutorial-Video für COSBench (Intel-Tool für BenchmarkingObjekt Cloud-Storage-Dienste) auf http://blog.zhaw.ch/icclab/shortvideo-introduction-to-cosbench/.

SIG CC: ICCLab MIT Senseable Besuch der Stadt Labin US http://blog.zhaw.ch/icclab/icclabvisiting-mit-senseable-city-lab/.

\section{Veranstaltungen}

Eine Übersicht über die Veranstaltungen und weitere Informationen finden Sie auf http://www.s-i.ch/ veranstaltungen/. 